\title{
Nitrate content and nitrogen loss in drainwater
}

\author{
G. J. Kolenbrander
}

Institute for Soil Fertility, Haren-Groningen, the Netherlands

Received 20 February 1969

\begin{abstract}
Summary
On cropped arable land the nitrate content of drainwater shows a distinct maximum in spring (March-May) and a minimum in autumn (November). On grassland it is more constant during the year, except when nitrogen is applied in autumn or winter (liquid manure, stable dung, liquid ammonia). In such cases the situation is the same as in cropped arable land. These fluctuations of the nitrate content of drainwater make it necessary to collect samples of the drainwater periodically during the whole year. In this way an average content of 1-2 $\mathrm{mg}$ per 1 was found for grassland, and of 4-10 mg per 1 for cropped arable land depending on the clay content (particles $<16 \mu \mathrm{m})$ of the soil.

From lysimeter experiments it is found that on cropped arable land $(350 \mathrm{~mm}$ drainwater per year) and from a soil profile of $100-125 \mathrm{~cm}$ with a clay content of $35 \%$ or more, little nitrogen is lost by leaching neither as mineralized nor as applied nitrogen. On sandy soils ( $0-10 \%$ clay), however, about $60 \mathrm{~kg} \mathrm{~N}$ per ha can be lost yearly, while also $20 \%$ of the applied fertilizer nitrogen is leached out of the profile.

On grassland leaching losses depend on the time of application of the nitrogen. A better distribution of the applied nitrogen during the growth season than on arable land and the high rate of nitrogen uptake by the grass reduce strongly the losses of applied nitrogen during the period March-June, even on sandy soils. Later on the losses can rise to a maximum of $40 \%$ of the nitrogen applied in November.
\end{abstract}

\section{Introduction}

The assessment of the yearly nitrate losses with drainage is a very complex problem. It depends on the amount and time of drainwater production but also on the nitrate content of the soil. The latter is the resultant of the amount of nitrogen mineralized by the soil, the nitrogen applied, the amount taken up by the crop and losses by leaching and denitrification.

Only when rainy periods, with a high drainwater production, coincide with high nitrate concentrations in the soil, losses of nitrates in drainwater are likely to be large. The vertical transport of nitrate from the upper layers to the drains, however, requires some time. Therefore, the increase in nitrate losses with water might appear when the wet period has ended. The leaching of nitrate from a layer with a high concentration on the surface of the soil after fertilization proceeds as a descending displacement of a 'concentration wave' in the profile. This vertical concentration wave will be found also in the drainwater, when this is sampled periodically. As the mean waterflow due to another distribution pattern of soil pores is much slower in 
a heavy clay soil than in a light sandy soil, leaching in the former is much less than in the sandy soil.

Overlooking the problem the conclusion can be that an incidental sampling of drainwater never can serve for the assessment of the mean nitrate concentration in the drainwater. Long-term experiments with frequent drainwater sampling are indispensable for that purpose. But accepting only experiments answering this requirement, there remain very few cases in the Netherlands which can be used. They are compiled in Table 1 and consist of two lysimeter trials on grassland (Kolenbrander, 1969) and one on arable land (Maschhaupt, 1941), and two drainage trials on arable land (Hudig and Welt, 1911; Engelhardt, 1935; Maschhaupt, 1941).

\section{Nitrate content of drainwater in the Netherlands}

The average nitrate content of drainwater during the year of the experiments mentioned above is drafted in Fig. 1. From this figure it becomes apparent that on heavy clay grassland (Experiment 1, unpublished results from the Rottegatspolder), with an application of fertilizer nitrogen $(3 \times 50 \mathrm{~kg} \mathrm{~N}$ per ha) during the growth season only, the nitrate content of the drainwater is low (about $1 \mathrm{mg}$ per 1), and remains practically constant during the whole year. When, however, the nitrogen is also applied during the winter, as in Experiment 2 on a light sandy soil (Woldendorp et al., 1965), an increase of the nitrate content is evident beginning in November and reaching a maximum in March. During the summer the nitrate concentration here also is very low and very similar to that in Experiment 1 on heavy clay soil.

In the Netherlands large amounts of nitrogen are generally applied as liquid manure on grassland in autumn and winter. Part of this nitrogen is oxidized to nitrate in

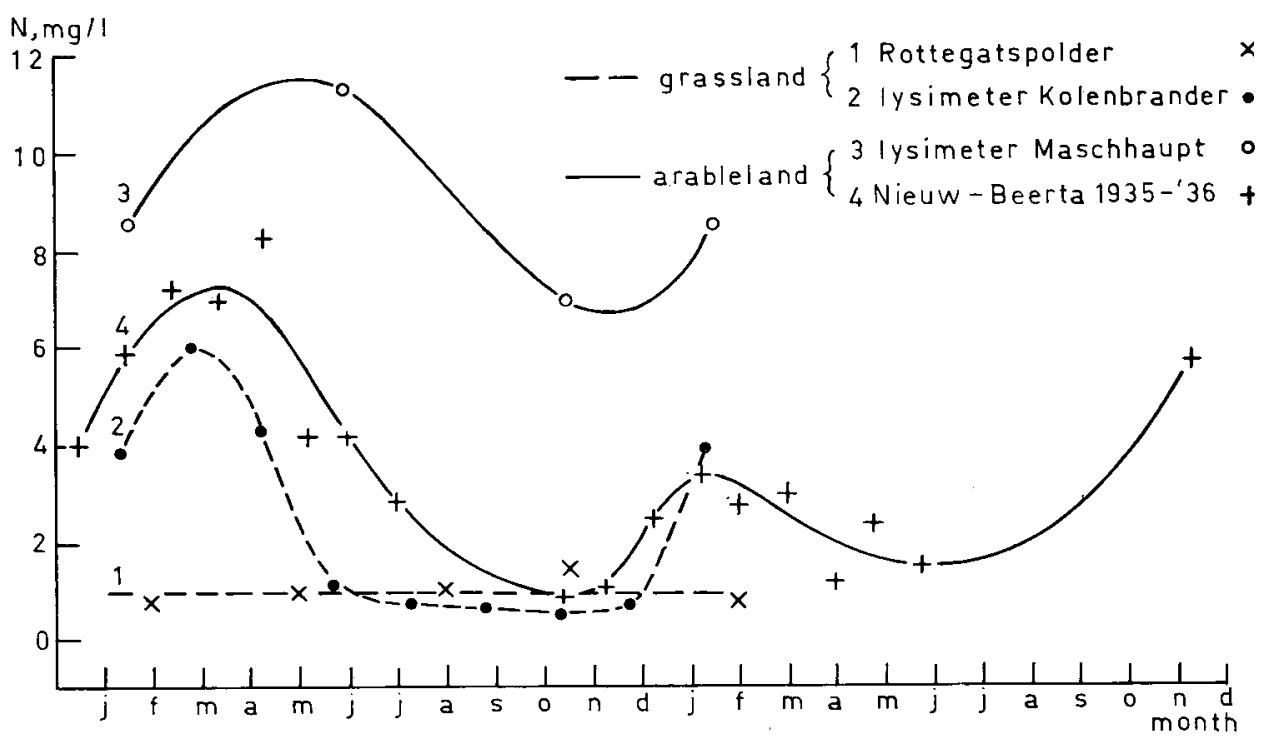

Fig. 1 The average nitrogen content of drainwater from different soils during the year 


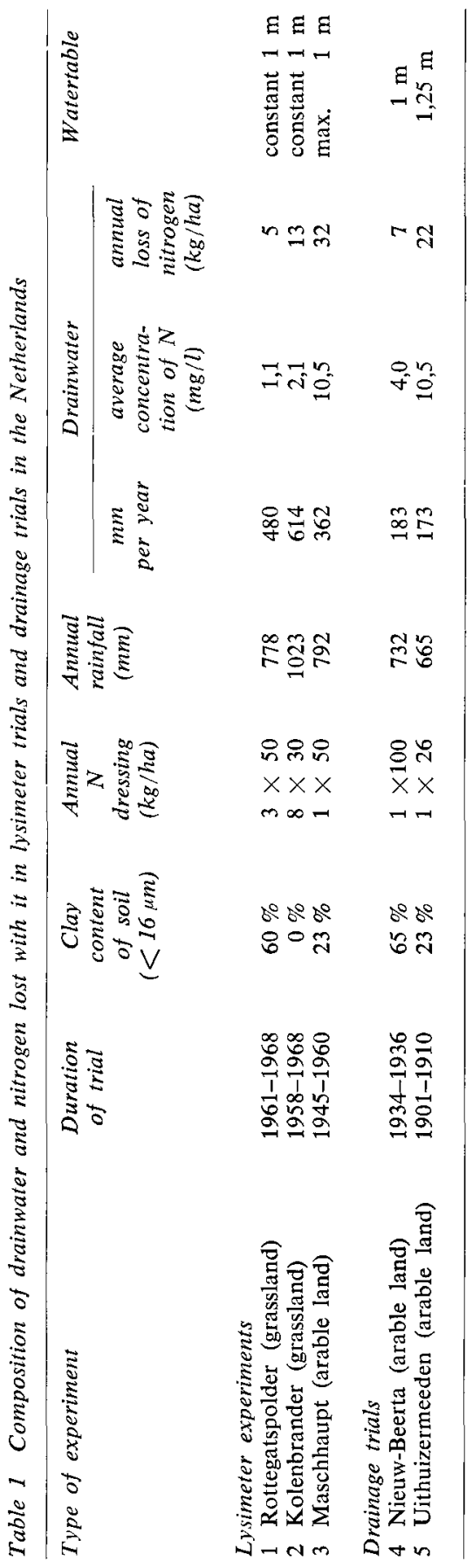


autumn, and about $50 \%$ of it is lost by leaching during autumn and winter. This situation can be considered normal on sandy soils.

On arable land a similar curve is found (Maschhaupt, 1941), but the mean concentration level is higher than on grassland. The top in spring is caused by mineralization, nitrification and leaching during autumn and winter of organic residues remaining in the soil after harvesting the crop.

The mean nitrate concentration of drainwater from cropped arable land being higher than that from grassland is brought about by the application of nitrogen at once and at a high rate in spring, while the velocity of the uptake of the nitrogen by the crop on arable land is lower. Experiment 4 (Engelhardt, 1935; Maschhaupt, 1941) maintained over two consecutive years shows that the concentration in the same soil can considerably differ from year to year.

The conclusion from these experiments is that in practice on cropped arable land and grassland the highest concentration of nitrate in the drainwater can be expected from March to May, the lowest in the period June-November. The mean nitrate content over the whole year will be higher on cropped arable land than on grassland. The number of experiments is, however, too small for a quantitative estimation of the mean yearly nitrate level in drainwater from arable land and grassland with different clay contents.

\section{Nitrogen losses bij leaching in cropped arable land}

The number of experiments in which the nitrogen losses by leaching have been determined is small in the Netherlands (Table 1). To obtain information it was decided to include also lysimeter results from other countries in this consideration. Fig. 2

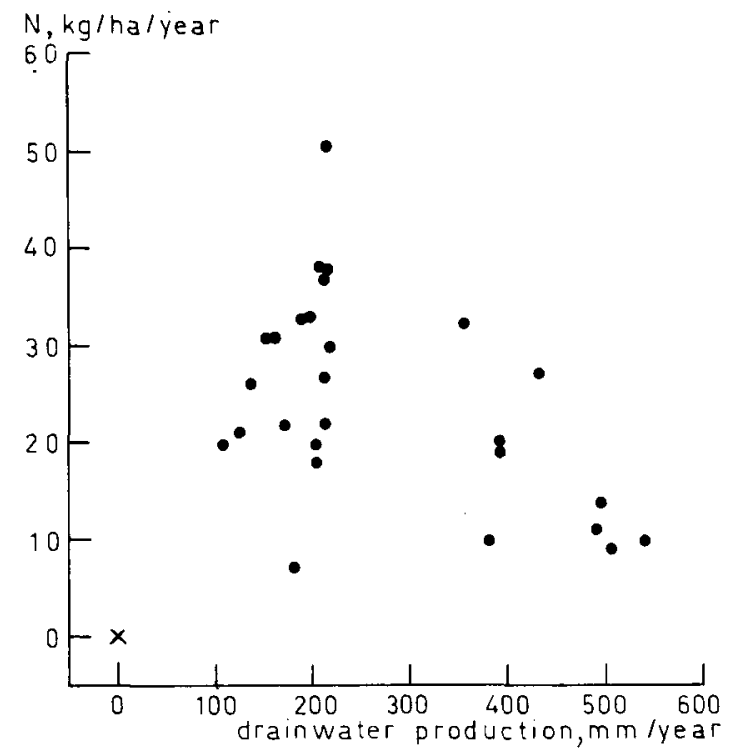

Fig. 2 Relation between nitrogen losses by leaching and drainwater production on cropped arable lysimeters (depth of the lysimeters $100-125 \mathrm{~cm}$ ) 
demonstrates the relation between the amount of nitrogen lost yearly by leaching and the amount of drainwater produced. These results are derived from studies by Lyon and Bizzell (1921), Gerlach (1926), Lyon et al. (1930), Maschhaupt (1941), Oedelien and Vidme (1945), Oedelien and Uhlen (1952), Reyes et al. (1961) and Pfaff (1963), and represent 'arable' lysimeters, cropped during 5-15 years, with a depth varying from 100 to $125 \mathrm{~cm}$.

The influence of the nitrogen applied and of the heaviness of the soil on these leaching losses can now be determined. Therefore we must, for the sake of easy calculation, start from the assumption that the relation between yearly drainwater production and nitrogen loss in a lysimeter is linear. So all lines pass through the orgin. Fig. 3 shows that this assumption is supported until $600 \mathrm{~mm}$ drainwater by the data of the Maschhaupt lysimeter. As the average yearly drainwater production in the Maschhaupt lysimeter (Experiment 3, Table 1) was $362 \mathrm{~mm}$, we have for all further considerations recalculated all losses to a drainwater production of $350 \mathrm{~mm}$ per year on cropped arable land. From Fig. 2 it becomes evident that also at the same drainwater production ( $350 \mathrm{~mm}$ per year) the nitrogen losses of the different lysimeters are showing a considerable fluctuation, ranging from 5 to $80 \mathrm{~kg} \mathrm{~N} / \mathrm{ha}$ per year, with a mean annual loss of about $40 \mathrm{~kg}$ per ha. This great fluctuation is caused by differences in soil texture and nitrogen fertilization.

As the drainage of $350 \mathrm{~mm}$ yearly is produced mainly in winter, we can make a comparison with experiments of van der Paauw $(1963 \mathrm{a}, \mathrm{b})$. In his investigation he found also a value of about $40 \mathrm{~kg} \mathrm{~N}$ per ha for the mean difference in available nitrogen between dry and wet winters in different field trials with a clay content

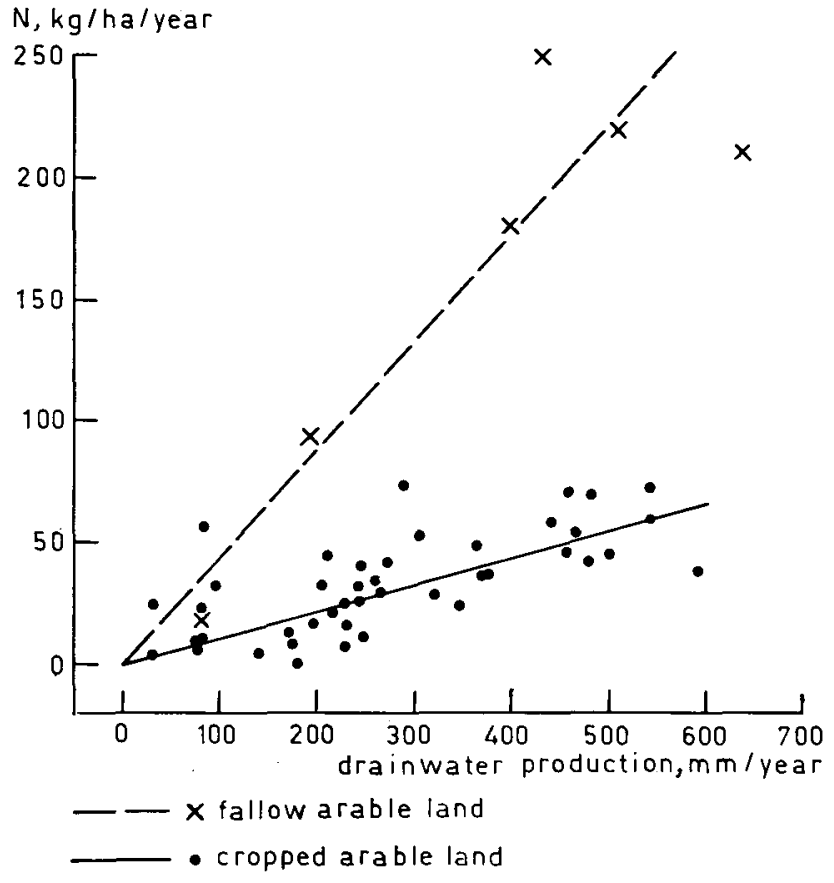

Fig. 3 Relation between the yearly drainwater production and nitrogen loss by leaching in the Maschhaupt lysimeter (curve 3 in Fig. 1) 
$(<16 \mu \mathrm{m})$ ranging from 0 to $50 \%$. In these experiments a winter was called wet when more than $250 \mathrm{~mm}$ rain had fallen from November to February, while after such a winter the mineral-nitrogen content of the soil is very small. Under our climatic conditions drainwater production in this period will be equal to rainfall.

Effect of soil texture on leaching losses of applied nitrogen

Fig. 4 shows the relation between amount of nitrogen applied and nitrogen lost by leaching (350 mm drainwater) for different lysimeters with soils of different clay contents (particles $<16 \mu \mathrm{m}$ ). These data are taken from Gerlach (1926), Oedelien and Vidme (1945), Reyes et al. (1961), and Pfaff (1963).

Fig. 5 is derived from Fig. 4 and shows the relation between the clay content $(<16 \mu \mathrm{m})$ of the soil and the percentage of the applied nitrogen lost by leaching at different levels of nitrogen fertilization. This figure shows that the yearly nitrogen losses from fertilizer nitrogen generally are small in soils with a clay content $(<16 \mu \mathrm{m})$ of more than $25-30 \%$.

Effect of soil texture on nitrogen losses by leaching on unmanured soils

In the above we discussed the effect of leaching on applied fertilizer nitrogen. But

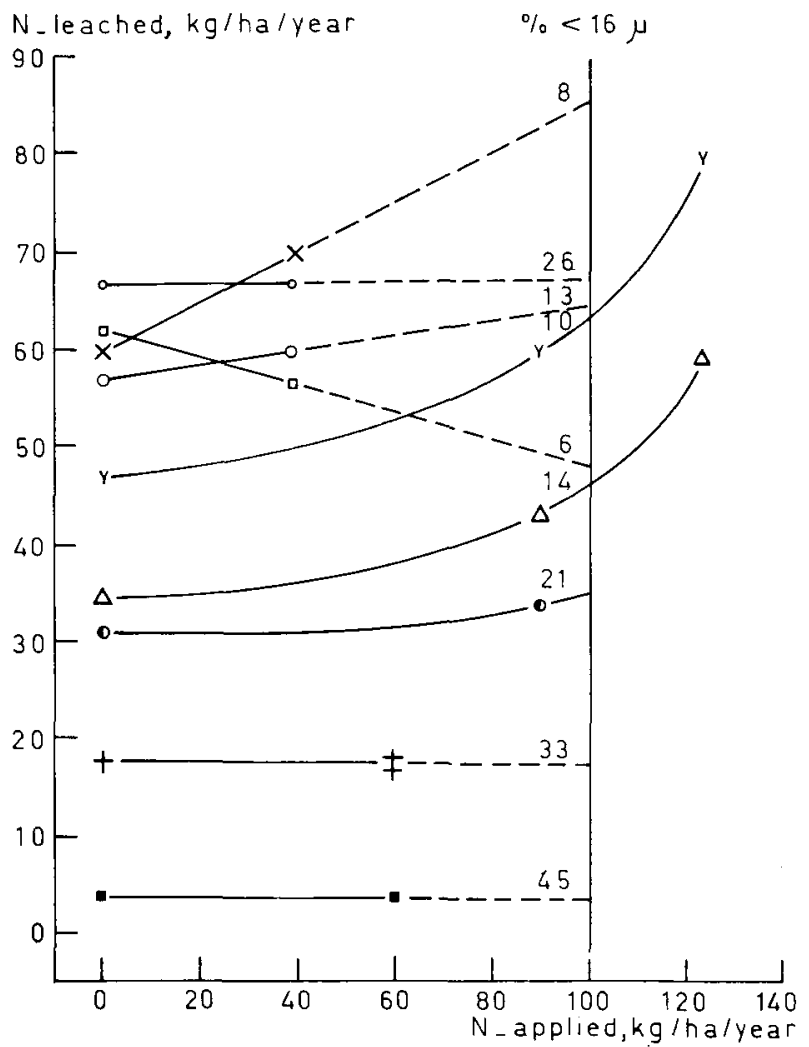

Fig. 4 Relation between $N$ applied and N-leached on cropped arable lysimeters with different heaviness of the soil, calculated for the standard. ized average drainwater production of $350 \mathrm{~mm}$ per year (depth lysimeters $100-110 \mathrm{~cm}$ ) -.. linear extrapolation 


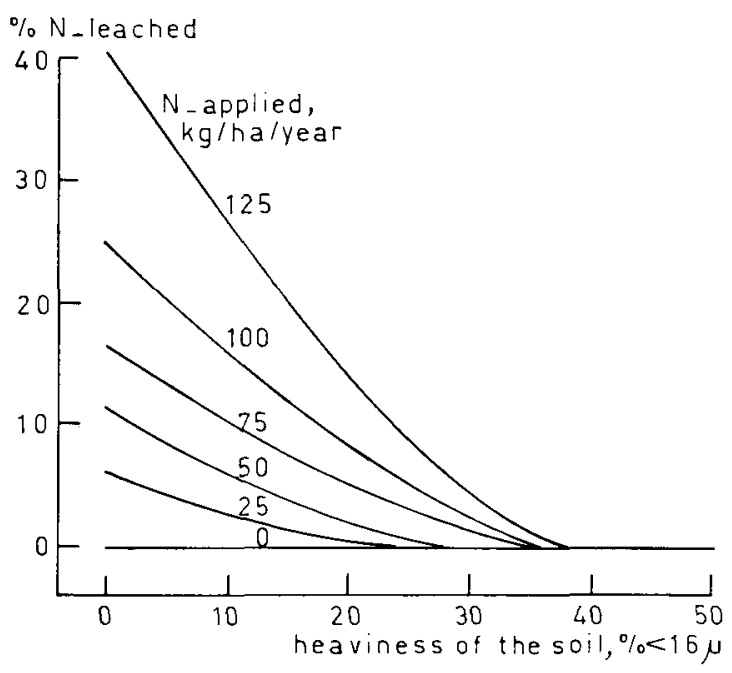

Fig. 5 Nitrogen losses (in \%) by leaching of the applied nitrogen fertilizer as a function of heaviness of the soil (350 $\mathrm{mm}$ drainwater, depth lysimeters 100$110 \mathrm{~cm}$ )

also the unmanured soil looses nitrogen by leaching. Fig. 6 shows the relation between soil texture and nitrogen losses by leaching on unmanured soils (at $350 \mathrm{~mm}$ drainwater per year and about $2 \%$ organic matter).

The results of the experiments on cropped arable land in the Netherlands are in good agreement with these foreign results, in spite of the fact that the Dutch experiments were fertilized with nitrogen. The fertilizer level and the texture of the soil,

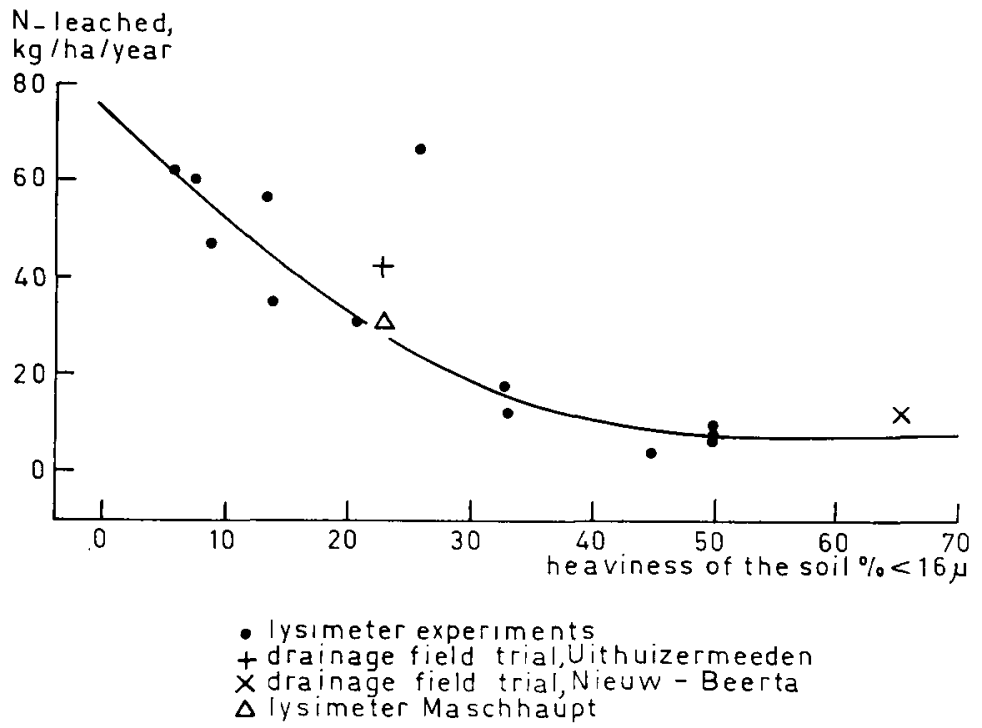

Fig. 6 Relation between heaviness of soil and nitrogen leached from cropped arable lysimeters with $2 \%$ organic matter in the soil and without nitrogen ferfilization (drainwater production $350 \mathrm{~mm}$ per year) 
however, are such that, according to Fig. 5, practically no nitrogen losses are to be expected after fertilization, and consequently these cases are comparable with unmanured objects.

The small leaching losses from fertilized and unfertilized clay soils in contrast to those on light soils are caused by the slow water movement in those profiles with a high percentage of water-filled small pores (Kolenbrander, 1969). On the other hand a great number of small pores filled with water will increase the anaerobic conditions in the profile and stimulate losses by denitrification, which result in smaller leaching losses.

Effect of organic matter on nitrogen losses by leaching

As amount and nature of the organic matter have an important effect on the quantity of nitrogen mineralized in soil, it must be assumed that nitrogen loss by leaching is affected by the humus content. No comparable experiment with varying organic matter content neither in our own work nor in the literature could be found, however, to test this supposition.

\section{Nitrogen losses by leaching on grassland}

There are less lysimeter experiments with grassland than with arable cropping. This makes it difficult to study the different factors influencing the losses by leaching on grassland.

Fig. 7, derived from the results of Lyon et al. (1930), Morgan and Jacobson (1942), Geering (1943), Bizzell (1944), Greenland (1959), Drover (1963), and Pfaff (1963), demonstrates that losses by leaching on unmanured grassland are small, as could be anticipated owing to the low level of mineral-nitrogen content throughout the year on unmanured grassland. The influence of the amount of rainfall also could not be spectacular. Even the effect of manuring is small, at least when manuring is restricted to the growth season and spread over several applications as usual in practice. Under these conditions with the average Dutch annual rate of $180 \mathrm{~kg} \mathrm{~N}$ per ha applied in 3-4 dressings, mineral nitrogen in the soil is kept low, while the velocity of nitrogen

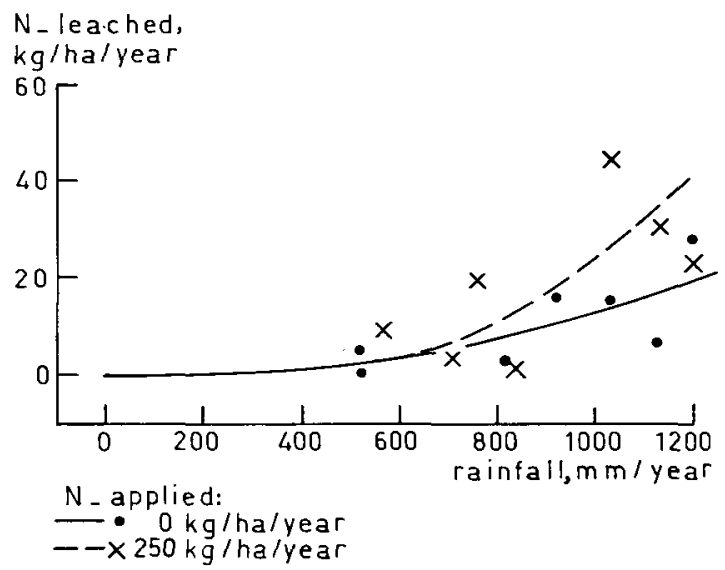

Fig. 7 Relation between rainfall and nitrogen losses by leaching in grassland 


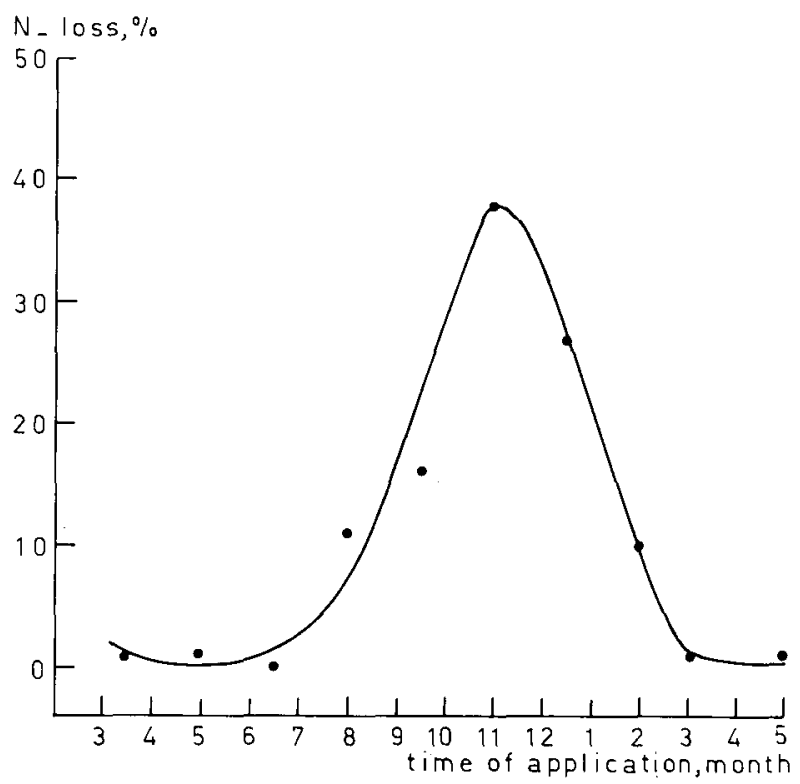

Fig. 8 Nitrogen losses by leaching in percents of the fertilizer nitrogen applied during the year in grassland on a sandy soil

uptake in the herbage is high, and - as the average rainfall in the Netherlands is about $750 \mathrm{~mm}$ per year - the annual loss by leaching from grassland can be estimated at $9 \mathrm{~kg} \mathrm{~N}$ per ha.

Nitrogen applied during autumn and winter is much more liable to leaching than that applied in spring and summer due to more rainfall and a slower uptake by the herbage. In Fig. 8 the leaching losses found in our experiments with grassland on a sandy soil are a clear example of this rule. Nearly $40 \%$ of the nitrogen applied in autumn (1 November) proved to be lost, while there was no loss at all in spring. In analogy with arable land these losses will be smaller on heavy soils.

Normally the dressing with fertilizer nitrogen is restricted to the growth season, but in the Netherlands much nitrogen is applied in autumn and winter as liquid and stable manure. During the autumn and mild winters part of this ammonia nitrogen is nitrified and lost by leaching in our wet winters. The effect of this autumn dressing is consequently about half that applied in spring.

\section{Conclusions}

1. The nitrate content of drainwater can fluctuate considerably during the year and from soil to soil, on arable land as well as on grassland. For an estimation of a correct average value periodical sampling will be necessary.

2. On soils with $35 \%$ or more clay (particles $<16 \mu \mathrm{m}$ ) not much nitrogen is lost due to leaching from a profile of $100-125 \mathrm{~cm}$. This holds for fertilizer nitrogen and for nitrate formed by mineralization.

3. Owing to the higher leaching losses on light soils the nitrate content of the drainwater will be higher on sandy soils than on heavy soils, at the same drainwater production. 


\section{NITRATE CONTENT AND NITROGEN LOSS IN DRAINWATER}

4. On grassland the nitrate content in the drainwater is very low (about 1-2 mg per 1) except when nitrogen is applied during autumn and winter.

\section{References}

Bizzell, J. A., 1944. Lysimeter experiments IV. Mem. Cornell Univ. agric. Exp. Stn 256, pp. 14.

Drover, D. P., 1963. Losses of nitrogen and other soil constituents from two soils in filled-in lysimeters. Aust. J. exp. Agric. Anim. Husb. 3: 105-113.

Engelhardt, J. H., 1955. De drainageproef op perceel 4. Versl. Ver. Exploit. Proefbedrijven Klei- en Zavelstreken Prov. Groningen, 1930-1934, p. 97-108.

Geering, J., 1943. Lysimeter Versuche. Landw. Jb. Schweiz 57: 107-182.

Gerlach, M., 1926. Untersuchungen über die Menge und Zusammensetzung der Sickerwässer. Landw. $J b r$ 64: 701-733.

Greenland, D. J., 1959. A lysimeter for nitrogen balance studies in tropical soil. $J l W$. Afr. Sci. Ass. 5: 79-89.

Hudig, J. en Welt, H., 1911. Het drainageproefveld te Uithuizermeeden. Versl. landbouwk. Onderz. 10, pp. 124.

Kolenbrander, G. J., 1969. Calculations of parameters for the evaluation of the leaching of salts under field conditions, illustrated by nitrate. VersI. Meded. Comm. hydrol. Onderz. T.N.O. 15: $59-73$.

Lyon, T. L. and Bizzell, J. A., 1921. Lysimeter experiments II. Mem. Cornell Univ. agric. Exp. Stn 41, pp. 93.

Lyon, T. L., Wilson, B. D. and Leland, E. W., 1930. Lysimeter experiments III. Mem. Cornell Univ. agric. Exp. Stn 134, pp. 72.

Maschhaupt, G. J., 1941. Lysimeteronderzoekingen aan het Landbouwkundig Proefstation te Groningen en elders. II. Versl. landbouwk. Onderz. 47: 165-528.

Morgan, M. F. and Jacobson, H. G. M., 1942. Soil and crop interrelation of various nitrogenous fertliizers. Bull. Conn. agric. Exp. Stn 458: 269-328.

Oedelien, M. og Uhlen, G., 1952. Lysimeterfors $\phi \mathrm{k}$ på Ås. I. Arl $\phi p s m e n g d e n ~ 1938-49$. II. Fors $\phi \mathrm{k}$ med kalhing og kaliumgjødsling 1943-46. Meld. Norg. LandbrHфgsk. Jordkulturfors $\phi k$ 36, pp. 39.

Oedelien, M. og Vidme, T., 1945. Lysimeterfors $\emptyset \mathrm{k}$ på Ås 1938-43. Meld. Norg. LandbrHфgsk. Jordkulturfors $\phi k 29$, pp. 90.

Paauw, F. van der, 1963a. Invloed van de regenval in de winter op de behoefte aan stikstof op verschillende grondsoorten. Landbouwvoorlichting 20: 102-107.

Paauw, F. van der, 1963b. Residual effect of nitrogen fertilizer on succeeding crops in a moderate marine climate. $P l$. Soil 19: 324-331.

Pfaff, C., 1963. Das Verhalten des Stickstoffs im Boden nach langjährigen Lysimeterversuche. $Z$. Acker- u PflBau 117: 77-99.

Reyes, E. D., Galvez, N. L. and Nazareno, N. B., 1961. Lysimeter studies on a lipa clay loam grown to paddy rice. I. Leaching losses of some soil constituents. Philipp. Agric. 45: 244-257.

Woldendorp, J. W., Dilz, K. and Kolenbrander, G. J., 1966. The fate of fertilizer nitrogen on permanent grassland soils. Proc. gen. Meeting Eur. Grassld Fed. 1, Wageningen, 1965, p. 53-76. 